\title{
Tissue-diet discrimination factors and turnover of stable carbon and nitrogen isotopes in white- footed mice (Peromyscus leucopus)
}

\author{
Rachel L. DeMots, James M. Novak, Karen F. Gaines, Aaron J. Gregor, \\ Christopher S. Romanek, and Daniel A. Soluk
}

\begin{abstract}
Stable isotope analysis has become an increasingly valuable tool in investigating animal ecology. Here we document the turnover rates for carbon in the liver, muscle, and whole blood tissue, as well as the tissue-diet discrimination values for carbon and nitrogen isotopes in the liver, whole blood, muscle, and hair, of the white-footed mouse (Peromyscus leucopus (Rafinesque, 1818)). A 168-day diet-switching experiment was conducted with a laboratory population of whitefooted mice. The $\delta^{13} \mathrm{C}$ values for all tissues deviated less than $1 \%$ from those of the diet except for whole blood, which had a slightly higher tissue-diet discrimination factor of $1.8 \%$. All tissues were enriched in ${ }^{15} \mathrm{~N}$ by approximately $3 \%$ relative to the diet except for liver tissue, which was $4.5 \%$ higher than the dietary $\delta^{15} \mathrm{~N}$ value. Turnover rates for tissues of white-footed mice were ranked liver $>$ whole blood $>$ muscle. The half-lives calculated for liver tissue differed significantly between the two diet switches performed in this experiment. We demonstrate that there is potential for variation in tissue-diet discrimination values and tissue turnover rates between even closely related species. These findings highlight the importance of determining species-specific estimates of these parameters prior to the use of stable isotope analysis in field investigations of animal ecology.
\end{abstract}

Résumé : L'analyse des isotopes stables devient un outil de plus en plus précieux dans l'étude écologique des animaux. Nous déterminons ici les taux de remplacement du carbone dans les tissus du foie, du muscle et du sang entier, ainsi que les valeurs de discrimination tissu-régime des isotopes de carbone et d'azote dans le foie, le sang entier, le muscle et le poil chez la souris à pieds blancs (Peromyscus leucopus (Rafinesque, 1818)). Nous avons mené une expérience de changement de régime alimentaire de 168 jours avec une population de laboratoire de souris à pieds blancs. Les valeurs de $\delta^{13} \mathrm{C}$ dans tous les tissus diffèrent de moins de $1 \%$ de celles du régime, excepté dans le sang entier qui possède un facteur de discrimination tissu-régime légèrement plus élevé de $1,8 \%$. Tous les tissus sont enrichis en ${ }^{15} \mathrm{~N}$ d'environ $3 \%$ par rapport au régime, excepté le tissu hépatique qui l'est de 4,5\% au-dessus de la valeur $\delta^{15} \mathrm{~N}$ du régime. Les taux de remplacement des tissus de la souris à pieds blancs sont par ordre foie > sang entier > muscle. Les demi-vies calculées pour le tissu hépatique sont significativement différentes dans les deux changements de régime faits au cours de l'expérience. Nous démontrons la possibilité de variation dans les valeurs de discrimination entre les tissus et le régime et dans les taux de remplacement des tissus même entre des espèces fortement apparentées. Ces observations soulignent l'importance de déterminer des estimations spécifiques à l'espèce de ces variables avant d'utiliser l'analyse des isotopes stables dans des recherches en nature en écologie animale.

[Traduit par la Rédaction]

\section{Introduction}

Stable carbon and nitrogen isotopes have been used successfully to gain important insights into the trophic relation-

Received 28 October 2009. Accepted 26 July 2010. Published on the NRC Research Press Web site at cjz.nrc.ca on 23 September 2010.

R.L. DeMots, ${ }^{1}$ A.J. Gregor, and D.A. Soluk. University of South Dakota, Department of Biology, 414 East Clark Street, Vermillion, SD 57069, USA.

J.M. Novak and K.F. Gaines. Eastern Illinois University, Department of Biological Sciences, 600 Lincoln Avenue, Charleston, IL 61920-3099, USA.

C.S. Romanek. Savannah River Ecology Laboratory,

P.O. Drawer E, Aiken, SC 29802, USA.

${ }^{1}$ Corresponding author (e-mail: rachel.demots@usd.edu). ships between organisms and origin of diet for many wildlife species (e.g., Drever et al. 2000; Romanek et al. 2000; Darimont and Reimchen 2002; Kurle and Worthy 2002). These isotope signatures can be traced through food webs because the isotope ratios of organisms reliably reflect those of the diet. Animals do not substantially alter the carbon isotopic composition of their food, therefore $\delta^{13} \mathrm{C}$ values generally reflect dietary carbon sources (Tieszen et al. 1983). In contrast, the $\delta^{15} \mathrm{~N}$ value in a consumer's tissues is generally enriched over dietary intake in a predictable manner. This feature of nitrogen isotopes allows their use as an indicator of a consumer's trophic position within a food web.

Two important processes influence how the stable isotope compositions of animal tissues are interpreted: (1) tissuediet discrimination factor and (2) tissue turnover rate. The difference in isotope composition between any tissue compartment of an animal and its diet is represented by a 
tissue-diet discrimination factor, " $\varepsilon_{\text {tissue-diet }}$ ", which is calculated as

$$
\varepsilon_{\text {tissue-diet }} \approx \delta_{\text {tissue }}-\delta_{\text {diet }}
$$

where $\delta$ is the delta value for the isotope of interest (Craig 1953). Tissue-diet discrimination factors are applied to a dietary source as a correction factor before sources are added to an isotopic model describing the contribution of various food resources in the diet of wild animals. Tissue turnover rate describes the residence time of an element (e.g., $\mathrm{C}$ or $\mathrm{N}$ ) in a particular tissue (e.g., liver or muscle) and is primarily a function of the rate of protein turnover associated with the tissue (Tieszen et al. 1983; Hobson and Clark 1992; Carleton and Martínez del Rio 2005). This process allows for dietary reconstruction, from a few days to near a lifetime, by measuring the isotope composition of a number of tissues within an individual (Dalerum and Angerbjörn 2005; Phillips and Eldridge 2006).

When investigating trophic relationships and creating isotopic models of diet, researchers often apply generalized, fixed tissue-diet discrimination factors for $\delta^{13} \mathrm{C}$ values (DeNiro and Epstein 1978; Peterson and Fry 1987) and $\delta^{15} \mathrm{~N}$ values (DeNiro and Epstein 1981; Minagawa and Wada 1984; Fry 1988; Vanderklift and Ponsard 2003). However, a number of poorly understood biophysical processes including rate of differential digestion and allocation of dietary components (Bearhop et al. 2002; Cherel et al. 2005; MacAvoy et al. 2005), diet quality (Tieszen and Farge 1993; Phillips and Koch 2002; Robbins et al. 2005; Mirón et al. 2006), or level of fat associated with a tissue (DeNiro and Epstein 1977; Post et al. 2007) may cause significant variation in tissue-diet discrimination factors and turnover rates of carbon and nitrogen among tissues in individuals and among species. The use of inaccurate tissue-diet discrimination values and turnover rates can introduce error into models of diet and result in incorrect assignments of trophic positions (McCutchan et al. 2003; Dalerum and Angerbjörn 2005). For example, Caut et al. (2008) demonstrated that using fixed tissue-diet discrimination factors (i.e., nonspeciesand nondiet-specific) led to less accurate calculations of diet components in Norway rats (Rattus norvegicus (Berkenhout, 1769)) than did models where the discrimination factors were species, tissue, and even diet dependant. Therefore, to use stable isotopic analysis to accurately model a consumer's diet and assess temporal feeding patterns and trophic positioning, species- and tissue-specific discrimination factors and turnover times must first be determined through controlled feeding experiments (Gannes et al. 1997).

Mice of the genus Peromyscus Gloger, 1841 are the most common native North American mammal. Because of their abundance, these animals constitute a major component of Nearctic terrestrial ecosystems and serve as a prey base for a wide array of predators (Jaksic et al. 1996; Sieg 1988; Collopy et al. 2000). Because of their ecological significance, Peromyscus spp. are often a focal species or an integral component of both basic and applied ecological research.

Tissue-diet discrimination values and tissue turnover rates have been measured for a limited number of small-mammal species such as the house mouse (Mus musculus L., 1758) (DeNiro and Epstein 1978; DeNiro and Epstein 1981; Arneson and MacAvoy 2005; MacAvoy et al. 2005; Arneson et al. 2006); the Norway rat (MacAvoy et al. 2006); the Mongolian jird (Meriones unguiculatus (Milne-Edwards, 1867)) (Tieszen et al. 1983), and most recently, for the deer mouse (Peromyscus maniculatus (Wagner, 1845)) (Miller et al. 2008). We conducted a captive feeding experiment with white-footed mouse (Peromyscus leucopus (Rafinesque, 1818)) to determine the turnover rates and tissue-diet discrimination factors for liver, whole blood, muscle, and hair. Our goal was to quantify the isotopic tissue-diet relationships for the species, which can then be used to interpret stable isotope data gathered for wild white-footed mice. We predicted that $(i)$ carbon tissue-diet discrimination would be minimal and that tissue would be approximately $3 \%$ enriched in ${ }^{15} \mathrm{~N}$ compared with diet; (ii) tissue with a high rate of protein turnover would show more rapid change in ${ }^{13} \mathrm{C}$ signature toward the dietary value compared with tissue that is replaced at a slower rate; and (iii) differences in rate of turnover would not vary according to dietary $\delta^{13} \mathrm{C}$.

\section{Materials and methods}

\section{Experimental population}

Twenty breeding pairs of mice were purchased from the Peromyscus Genetic Stock Center (University of South Carolina) and housed under standard laboratory conditions. Animal care and treatment protocols were approved by the University of South Dakota Institutional Animal Care and Use Committee and were in accordance with the principles outlined in the 1998 Animal Care and Use guidelines published by The American Society of Mammalogists. From the breeding pairs, 138 mice were bred. All mice used in the feeding trial were bred from mice consuming Harlan Rodent Chow \#8604 diet for 2 months prior to breeding and were weaned on the Harlan diet for at least 2 weeks before the start of the experiment. Mice were identified with a passive integrated transponder (PIT) tag and were older than 55 days at the start of the feeding trial.

\section{Diet-switching experiment}

Mice were split into two groups: a control group that remained on the Harlan diet $(n=15)$ and an experimental group $(n=78)$. The experimental mice were fed a diet consisting of ground corn and corn dry distillers grain solids mixed with a vitamin and mineral supplement on day 0 (hereafter referred to as "diet switch 1"). On day 78, 36 of the mice were switched back to the Harlan diet (hereafter referred to as "diet switch 2") and 12 of the mice were continued on the corn diet. Diets were chosen to be isotopically distinct. Food and water were available ad libitum throughout the study. Diets were sampled for carbon and nitrogen isotope analysis before the start of the feeding trial and once a month during the course of the study $(n=6)$. The experiment lasted 168 days.

Three control mice were sacrificed at the start of the feeding trial to determine baseline tissue isotope values and every 6 weeks thereafter throughout the experiment totaling five control population sampling events. Six experimental mice were sacrificed during each experimental population sampling event that occurred on days $0,7,14,28,70,98$, and 126 in diet switch 1 and days 77, 84, 91, 98, 126, and 128 in diet switch 2 . All mice were euthanized using inhaled 
isoflurane followed by cervical dislocation. Given that one of the goals of this experiment was to determine tissuediscrimination values for tissues likely to be collected from wild Peromyscus mice, and whole blood is easiest to collect in the field because it does not require centrifugation, we chose to sample whole blood rather than its constituents (i.e., plama and red blood cells). Whole blood tissue was obtained by cardiac puncture during the time of euthanization. Liver, muscle, and hair samples were obtained via dissection. Skeletal muscle was obtained from the quadriceps of the left leg. Tissues were frozen immediately after collection until they were processed for stable isotopes. All mice were weighed biweekly and the growth rate for each mouse was determined by dividing the change in mass from the first day of the diet switch to euthanization by the number of days the mouse was consuming the experimental diet.

\section{Sample preparation for isotopic analysis}

All tissue samples were dried in a drying oven at $60{ }^{\circ} \mathrm{C}$ for $72 \mathrm{~h}$. Samples of liver, muscle, and hair were cut into very small pieces and lipid-extracted for $24 \mathrm{~h}$ in a 2:1 chloroform to methanol solution (Bligh and Dyer 1959). Dissolved lipids were manually extracted with a pipette. Samples were subsequently rinsed for several minutes until the solvent wash ran completely clear. Following extraction, samples were kept uncovered under a fume hood at room temperature until all the residual solvent had evaporated. Samples were then turned into powder with a mortar and pestle and 1.0-2.0 mg subsamples were packed in precleaned tin capsules for isotope analysis.

\section{Isotopic analysis}

Elemental analysis - isotope ratio mass spectrometry (EAIRMS) was employed to obtain isotope ratios of samples. All measurements were performed at the Stable Isotope Laboratory at the University of Georgia's Savannah River Ecology Laboratory. Samples were loaded in the autosampler of a Carlo Erba Elemental Analyzer (NA 2500) attached to a continuous flow isotope ratio mass spectrometer (Finnigan Delta Plus XL). Stable isotope ratios are reported in per mil units $(\%)$ using standard delta $(\delta)$ notation as follows:

$$
\delta X=\left[\left(R_{\text {sample }} / R_{\text {standard }}\right)-1\right] \times 1000
$$

where $X$ is ${ }^{13} \mathrm{C}$ or ${ }^{15} \mathrm{~N}$ and $R_{\text {sample }}$ and $R_{\text {standard }}$ are the corresponding ratios of the rare to common isotopes $\left({ }^{13} \mathrm{C} /{ }^{12} \mathrm{C}\right.$ or ${ }^{15} \mathrm{~N} /{ }^{14} \mathrm{~N}$ ) in the sample and an international standard (Pee Dee belemnite and atmospheric $\mathrm{N}_{2}$ ), respectively. Measurements were calibrated against in-house reference standards (powdered dogfish muscle (DORM) and Acetanilide) of known $\delta^{13} \mathrm{C}$ and $\delta^{15} \mathrm{~N}$ values. Every 10th sample was analyzed in duplicate and resulted in sample precision of $\pm 0.2 \%$ for $\delta^{13} \mathrm{C}$ and $\delta^{15} \mathrm{~N}$.

The stable carbon isotopes values were determined for liver tissues sampled on days $0,7,14,28,70,98$, and 126 of diet switch $1(n=42)$ and on days 77, 84, 91, 98, 126, and 168 of diet switch $2(n=36)$. For muscle, isotope values were determined for tissues sampled on days $0,14,28$, 42, 70, and 98 of diet switch $1(n=36)$ and on days 77, 98, 126, and 168 of diet switch $2(n=24)$. For whole blood, isotope values were determined for tissues sampled on days
$0,28,70,98$, and 126 of diet switch $1(n=30)$ and on days $77,98,126$, and 168 of diet switch $2(n=24)$.

\section{Modeling and statistical analysis}

Tissue-diet discrimination factors were determined by comparing the mean $\delta^{13} \mathrm{C}$ and $\delta^{15} \mathrm{~N}$ values of the bulk diet (Harlan diet) to the mean values of each tissue from six mice sacrificed at the beginning of the feeding trial. Analysis of variance (ANOVA) and post hoc Tukey's honestly significant difference (HSD) tests were performed to determine significant differences in $\delta^{13} \mathrm{C}$ or $\delta^{15} \mathrm{~N}$ between diet and tissues and among tissues. Normality of all dependent variables was tested before fitting models and the homogeneity of variances between data sets was evaluated using an $F$ test. Relationships between body mass changes and carbon and nitrogen turnover rates were analyzed using a Pearson's simple correlation test statistic. Measurements of mean $\delta^{13} \mathrm{C}$ and $\delta^{15} \mathrm{~N}$ values are expressed as means \pm SD. Significance was tested at the $\alpha=0.05$ level.

Because patterns of carbon turnover in the mouse tissues behaved according to negative exponential models, exponential decay curves of the type

$$
y=a \mathrm{e}^{(-b x)}+c
$$

were used to model turnover rates, where $a$ is the overall change in $\delta^{13} \mathrm{C}$ value associated with the change in diet, $c$ is the asymptotic ${ }^{13} \mathrm{C}$ value of the tissue, and $b$ is the fractional turnover rate. Fits were constructed for liver, blood, and muscle data using PROC NLIN in SAS (SAS Institute Inc. 1985). Turnover was not modeled for nitrogen because $\delta^{15} \mathrm{~N}$ values in both diets were similar. The half-life of ${ }^{13} \mathrm{C}$ in liver, muscle, and whole blood was calculated using

$$
T=\frac{\ln 0.5}{b}
$$

where $T$ is the half-life in days (Tieszen et al. 1983). All statistical computations were performed with SAS (SAS Institute Inc. 1985).

\section{Results}

\section{Fractionation of isotopes}

The $\delta^{13} \mathrm{C}$ and $\delta^{15} \mathrm{~N}$ values of the Harlan diet were consistent throughout the course of the study and averaged $-19.7 \%$ $0.3 \%$ and $2.8 \% \pm 0.1 \%$, respectively. The $\delta^{13} \mathrm{C}$ and $\delta^{15} \mathrm{~N}$ values of the corn diet were also consistent for the duration of the experiment and averaged $-10.9 \%$ $\pm 0.2 \%$ and $2.3 \% \pm 0.1 \%$, respectively. Tissue-diet discrimination factors for both carbon and nitrogen isotopes were determined in liver, muscle, hair, and whole blood. At the beginning of the experiment, the mean $\delta^{13} \mathrm{C}$ values of the liver $(-20.3 \%$ $\pm 0.3 \%$ ) , muscle $(-20.4 \%$ o $\pm 0.2 \%$ ), whole blood $(-21.5 \% \pm 0.1 \%$ ) , and hair $(-20.8 \%$ $\pm 0.7 \%$ ) were significantly lower from that of the diet by $0.5 \%$ o $\pm 0.3 \%$, $0.7 \%$ o $0.2 \%$, $1.8 \% \pm 0.1 \%$, and $1.1 \%$ $\pm 0.7 \%$, respectively $(P<0.05$ for all comparisons). Whole blood had the lowest $\delta^{13} \mathrm{C}$ value and differed significantly from all other tissues $(P<0.001$ for each comparison). The stable carbon isotope values of muscle, hair, and liver were not significantly different from each other ( $P>0.5$ for each comparison). 
Mean $\delta^{15} \mathrm{~N}$ values of all tissues (liver $=7.4 \%$ $\pm 0.1 \%$, muscle $=6.1 \% \pm \pm 0.2 \%$, whole blood $=6.3 \% \pm \pm 0.2 \%$, and hair $=5.8 \%$ o $\pm 0.3 \%$ ) at the start of the experiment were significantly greater than the diet by approximately $4.5 \% \pm$ $0.1 \%$, 3.2\%o $\pm 0.2 \%$, 3.4\%o $\pm 0.2 \%$, and $2.9 \pm 0.1 \%$, respectively $(P<0.0001$ for all comparisons). Multiple comparisons between tissues indicated that all tissue pairs differed significantly in mean $\delta^{15} \mathrm{~N}$ values $(P<0.05$ for all comparisons).

\section{Estimating carbon turnover rate}

Single-pool exponential decay curves were fit to the $\delta^{13} \mathrm{C}$ values measured at each sampling point for liver, blood, and muscle during diet switch 1 and diet switch 2 . The curves fit well for all tissues and both diet switches with $r^{2}$ values ranging from 0.92-0.99 (Fig. 1). Calculated half-lives for the $\delta^{13} \mathrm{C}$ fractional turnover of carbon isotopes differed significantly between all tissues with liver turning over most rapidly during both diet switches, followed by whole blood, and then by muscle, which turned over the slowest (Table 1). The half-lives calculated for whole blood and liver tissue were slightly longer for diet switch 1 than diet switch 2 , with the half-life of liver tissue differing significantly between the two diet switches (Table 1). During the experiment, only liver appeared to have exhibited complete turnover with $99.99 \%$ of its carbon replaced by the new diet after 74 days in diet switch 1 and 50 days in diet switch 2 .

There was a mean mass gain of $2 \mathrm{~g}$ for mice throughout the experiment as adult mice tend to accumulate fat even after reaching the adulthood. No significant differences were observed in amount of mass gain between mice in diet switch 1 and diet switch $2(P=0.14)$. Carbon and nitrogen turnover rates were not correlated with body mass change during either of the diet switches $\left(r^{2}=-0.18, P=0.17\right.$ for carbon; $r^{2}=0.01, P=0.9$ for nitrogen). As anticipated, given that we were using nonbreeding adult mice, there were no gender-related differences in rate of turnover or tissue-diet discrimination factors $(P>0.05$ for all comparisons).

\section{Discussion}

\section{Discrimination factors for carbon and nitrogen isotopes}

Our calculations of tissue-diet discrimination values of $<1.0 \%$ for carbon isotopes in the liver, muscle, and hair of white-footed mice is consistent with the common notion that the $\delta^{13} \mathrm{C}$ values of tissues generally reflect dietary $\delta^{13} \mathrm{C}$ with negligible discrimination. However, we found whole blood to have a slight but significantly higher mean discrimination value of $1.8 \%$. Whole blood samples were not lipidextracted in this study. Although it is well known that plasma's lipid content is generally large enough to significantly alter the $\delta^{13} \mathrm{C}$ signature of the tissue relative to other tissues, there is uncertainty as to whether the percentage of lipids in whole blood is sufficient to produce changes in the bulk $\delta^{13} \mathrm{C}$ value of the tissue. Additionally, because the blood cells in whole blood contribute organic matter to the sample that plasma is lacking, and organic matter mediates the effects of lipids on carbon isotope ratios, whole blood often exhibits a carbon isotopic signature that is little affected by lipid content of the plasma (Cherel et al. 2005). Likewise,
Fig. 1. The change in mean $\delta^{13} \mathrm{C}$ values of $(a)$ liver, $(b)$ muscle, and $(c)$ whole blood of white-footed mice (Peromyscus leucopus) over time. Diet switch 1 (from the Harlan diet to the corn diet) is represented by diamonds (appears in blue on the Web) and diet switch 2 (from the corn diet back to the Harlan diet) is represented by squares (appears in magenta on the Web). Control mice are shown as triangles (appears in orange-red on the Web). Points represent the mean ${ }^{13} \mathrm{C}$ values at each sampling time (for diamonds and squares, $n=6$; for triangles, $n=4)$. Bars represent $\pm 1 \mathrm{SD}$. The dotted line (appears in black on the Web) represents the $\delta^{13} \mathrm{C}$ value of the Harlan diet and the broken line (appears in green on the Web) represents the $\delta^{13} \mathrm{C}$ value of the corn diet.
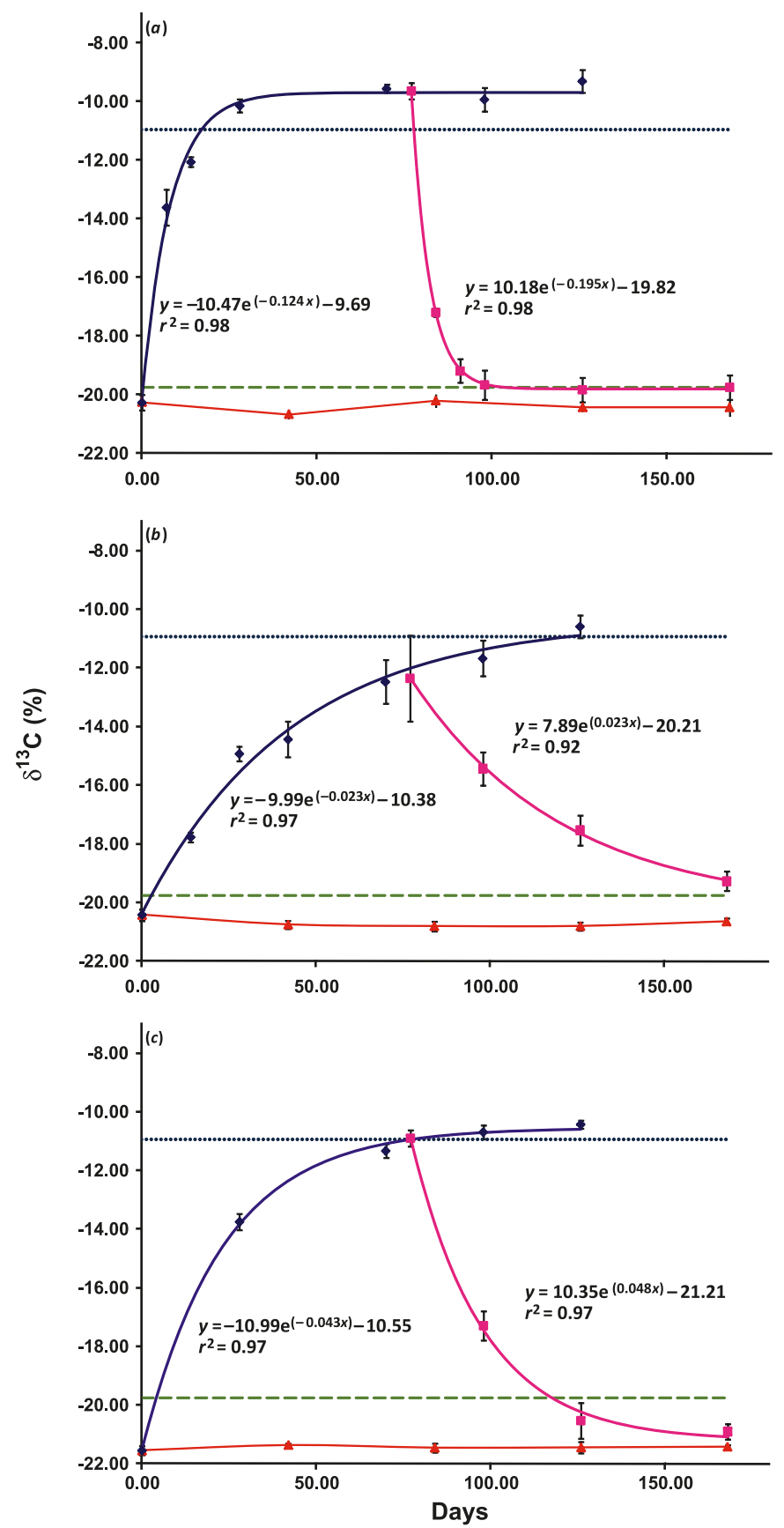

several studies have documented that the extraction of lipids from the whole blood of birds did not significantly alter the resulting $\delta^{13} \mathrm{C}$ values (Bearhop et al. 2000, 2002; Cherel et 
Table 1. Half-life (days) estimates of carbon isotopes in the tissues of white-footed mice (Peromyscus leucopus) sampled during diet switch 1 and diet switch 2 .

\begin{tabular}{lcclcc}
\hline & \multicolumn{2}{c}{ Diet switch 1 } & & \multicolumn{2}{c}{ Diet switch 2 } \\
\cline { 2 - 3 } \cline { 5 - 6 } Tissue & Mean & $95 \%$ CI & & Mean & $95 \%$ CI \\
\hline Liver & 5.6 & $5.1-6.2$ & & 3.5 & $3.2-4.0$ \\
Whole blood & 16.1 & $16.1-17.3$ & & 14.4 & $12.5-16.9$ \\
Muscle & 29.6 & $25.2-36.0$ & & 30.1 & $22.0-62.4$ \\
\hline
\end{tabular}

al. 2005). Nonetheless, because we do not have a direct assessment of the percentage of lipid in the whole blood samples from the white-footed mice, it is possible, although unlikely, that the inclusion of lipids in the blood may have resulted in a larger tissue-diet discrimination value than tissues that were lipid-extracted.

The tissue-discrimination values for carbon isotopes determined here for liver, muscle, and hair of white-footed mice are similar to those reported by Miller et al. (2008) for the closely related deer mouse with one exception; the $\delta^{13} \mathrm{C}$ discrimination value of whole blood in this experiment was determined to be $1.6 \%$ lower than that calculated for the deer mouse. This difference is surprising given that in both experiments, mice were fed diets with similar constituents, proteins of comparable biological value and similar carbon isotope ratios $(-19.4 \%$ o $\pm 0.3 \%$ in the Miller et al. (2008) study and $-19.7 \%$ o $\pm 0.3 \%$ in the current study). Likewise, in both experiments, whole blood tissues, as well as diets, were not lipid-extracted prior to isotopic analysis. As previously recognized by several researchers (Hobson and Clark 1992; Caut et al. 2008; Crawford et al. 2008), this observation highlights the need for the use of species-specific tissue-diet discrimination values in construction of mixing models to avoid errors in output. Alternatively, studies identifying quantifiable patterns of variation in this parameter across species would alleviate the need for labor-intensive investigations of tissue-diet discriminations in individual species.

In this study, the $\delta^{15} \mathrm{~N}$ values of muscle, whole blood, and hair were all approximately 3\%o greater than the diet and enriched in the same pattern observed in other studies of mammalian tissues (MacAvoy et al. 2005; Miller et al. 2008). However, the mean $\delta^{15} \mathrm{~N}$ value of the liver was approximately $4.5 \%$ higher than that of the initial diet and significantly higher than the other tissues sampled. This increase in the $\delta^{15} \mathrm{~N}$ value of liver over other tissues has been reported by Arneson and MacAvoy (2005) and MacAvoy et al. (2005), and suggests a differential fractionation of nitrogen occurring in liver tissue. Protein utilization exceeds dietary intake by approximately five times, because there is significant recycling of protein during synthesis of metabolically active tissues (Ayliffe et al. 2004). The high metabolic rate of the liver and the reuse of proteins as metabolic intermediates most likely results in higher $\delta^{15} \mathrm{~N}$ tissue-diet discrimination values in liver tissue compared with other tissues.

\section{Turnover rates of carbon isotopes}

The turnover rates found here were similar to those reported for the same tissues in house mice (Arneson et al. 2006), with liver tissue turning over most rapidly, followed by whole blood tissue, and with muscle tissue turning over most slowly. However, these findings differ from those recorded for deer mice (Miller et al. 2008), whereby muscle tissue turned over faster than whole blood. Again, these results are perplexing given that both experiments employed similar methodology. It is possible that these findings are a result of species-level differences in metabolism or nutrient routing. Consequently, it may be necessary to conduct additional controlled experiments specifically investigating these processes to determine what factors are indeed responsible for disparity between closely related species in estimations of turnover rates.

Interestingly, in our study of white-footed mice, the halflives calculated for carbon isotopes in tissues during diet switch 1 were longer than those for diet switch 2 for liver and whole blood tissue, with the half-life for liver being significantly different between the two diet switches. Muscle tissue did not exhibit the same trend; in fact the half-lives were somewhat shorter, although not significantly, during diet switch 2 than diet switch 1 . The Harlan diet contained $24 \%$ protein and $4 \%$ fat, whereas the corn diet contained $13 \%$ protein and $3.5 \%$ fat. Decreases in dietary protein levels can result in the increase in retention times of ${ }^{13} \mathrm{C}$ and ${ }^{15} \mathrm{~N}$ (Tsahar et al. 2007) owing to recycling of endogenous amino acids. These effects are usually only discernable in tissues that exhibit a high rate of protein turnover such as blood and liver. Therefore, the different rates of turnover in the liver and whole blood observed in this study may be explained by biophysical response to lower dietary quality (Phillips and Koch 2002; Cherel et al. 2005 ) in the corn diet (diet switch 1) relative to the Harlan diet (diet switch 2).

Because these feeding trials were conducted with whitefooted mice restrained to cages, as is necessary in experiments with tightly controlled diets, it is possible that our results underestimate turnover rates compared with wild mice with potentially higher field metabolic rates. However, increased metabolism does not necessarily equate to increased elemental turnover of tissues compartments (Carleton and Martínez del Rio 2005). Further studies are needed to determine the extent to which the metabolic rate of wild whitefooted mice and laboratory-raised mice differ from each other, and if these differences, if any, affect protein turnover in tissues.

Diet isotopic composition, isotopic routing, tissue turnover rates, and tissue-diet discrimination can all impact on isotopic composition of consumer tissues. It is critical for investigators to address how each of these processes affect the use of stable isotopes as diet indicators in a particular species before applying the technique to field systems. Failure to do so can result in less than optimal assessments of dietary histories and incorrect trophic position assignments. Our approximations of isotopic tissue-diet discrimination values and tissue turnover rates provide the best available information for establishing consistent and accurate methodology of stable isotope analysis for white-footed mice.

To improve further on accuracy of tissue-diet discrimination values and tissue turnover rates for white-footed mice, we suggest further feeding trials that $(i)$ include detailed isotopic analysis of macronutrients isolated from the diet to investigate potential effects of routing and (ii) investigate the 
importance of diet quality on recycling rates of stored proteins.

\section{Acknowledgements}

We thank the Savannah River Ecological Laboratory for the use of laboratory facilities. This study was funded in part by the Missouri River Institute and the University of South Dakota.

\section{References}

Arneson, L.S., and MacAvoy, S.E. 2005. Carbon, nitrogen, and sulfur diet-tissue discrimination in mouse tissues. Can. J. Zool. 83(7): 989-995. doi:10.1139/z05-083.

Arneson, L.S., MacAvoy, S.E., and Basset, E. 2006. Metabolic protein replacement drives tissue turnover in adult mice. Can. J. Zool. 84(7): 992-1002. doi:10.1139/Z06-081.

Ayliffe, L.K., Cerling, T.E., Robinson, T., West, A.G., Sponheimer, M., Passey, B.H., Hammer, J., Roeder, B., Dearing, M.D., and Ehleringer, J.R. 2004. Turnover of carbon isotopes in tail hair and breath $\mathrm{CO}_{2}$ of horses fed an isotopically varied diet. Oecologia (Berl.), 139(1): 11-22. doi:10.1007/s00442-0031479-x.

Bearhop, S., Teece, M.A., Waldron, S., and Furness, R.W. 2000. The influence of lipid and uric acid upon $\delta^{13} \mathrm{C}$ and $\delta^{15} \mathrm{~N}$ values of avian blood: implications for trophic studies. Auk, 117(2): 504-507. doi:10.1642/0004-8038(2000)117[0504:IOLAUA]2.0. $\mathrm{CO} ; 2$.

Bearhop, S., Waldron, S., Votier, S.C., and Furness, R.W. 2002. Factors that influence assimilation rates and fractionation of nitrogen and carbon stable isotopes in avian blood and feathers. Physiol. Biochem. Zool. 75(5): 451-458. doi:10.1086/342800. PMID:12529846.

Bligh, E.G., and Dyer, W.J. 1959. A rapid method of total lipid extraction and purification. Can. J. Biochem. Physiol. 37(8): 911917. PMID:13671378.

Carleton, S.A., and Martínez del Rio, C. 2005. The effect of coldinduced increased metabolic rate on the rate of ${ }^{13} \mathrm{C}$ and ${ }^{15} \mathrm{~N}$ incorporation in house sparrows (Passer domesticus). Oecologia (Berl.), 144(2): 226-232. doi:10.1007/s00442-005-0066-8.

Caut, S., Angulo, E., and Courchamp, F. 2008. Caution on isotopic model use for analyses of consumer diet. Can. J. Zool. 86(5): 438-445. doi:10.1139/Z08-012.

Cherel, Y., Hobson, K.A., Bailleul, F., and Groscolas, R. 2005. Nutrition, physiology, and stable isotopes: new information from fasting and molting penguins. Ecology, 86(11): 2881-2888. doi:10.1890/05-0562.

Collopy, D., Mannion, K., and Mynsberge, A. 2000. Small mammals are integral to the maintenance of the tallgrass prairie. Tillers, 3: 58-65.

Craig, H. 1953. The geochemistry of the stable carbon isotopes. Geochim. Cosmochim. Acta, 3(2-3): 53-92. doi:10.1016/00167037(53)90001-5.

Crawford, K., McDonald, R.A., and Bearhop, S. 2008. Applications of stable isotope techniques to the ecology of mammals. Mammal Rev. 38(1): 87-107. doi:10.1111/j.1365-2907.2008. 00120.x.

Dalerum, F., and Angerbjörn, A. 2005. Resolving temporal variation in vertebrate diets using naturally occurring stable isotopes. Oecologia (Berl.), 144(4): 647-658. doi:10.1007/s00442-0050118-0.

Darimont, C.T., and Reimchen, T.E. 2002. Intra-hair stable isotope analysis implies seasonal shift to salmon in gray wolf diet. Can. J. Zool. 80(9): 1638-1642. doi:10.1139/z02-149.
DeNiro, M.J., and Epstein, S. 1977. Mechanism of carbon isotope fractionation associated with lipid synthesis. Science (Washington, D.C.), 197(4300): 261-263. doi:10.1126/science. 327543. PMID:327543.

DeNiro, M.J., and Epstein, S. 1978. Influence of diet on the distribution of carbon isotopes in animals. Geochim. Cosmochim. Acta, 42(5): 495-506. doi:10.1016/0016-7037(78)90199-0.

DeNiro, M.J., and Epstein, S. 1981. Influence of diet on the distribution of nitrogen isotopes in animals. Geochim. Cosmochim. Acta, 45(3): 341-351. doi:10.1016/0016-7037(81)90244-1.

Drever, M.C., Blight, L.K., Hobson, K.A., and Bertram, D.F. 2000. Predation on seabird eggs by Keen's mice (Peromyscus keeni): using stable isotopes to decipher the diet of a terrestrial omnivore on a remote offshore island. Can. J. Zool. 78(11): 2010 2018. doi:10.1139/cjz-78-11-2010.

Fry, B. 1988. Food web structure on Georges Bank from stable C, $\mathrm{N}$, and S isotopic composition. Limnol. Oceanogr. 33(5): 11821190. doi:10.4319/lo.1988.33.5.1182.

Gannes, L., O’Brien, D.M., and Martínez del Rio, C. 1997. Stable isotopes in animal ecology: assumptions, caveats, and a call for more laboratory experiments. Ecology, 78(4): 1271-1276. doi:10.1890/0012-9658(1997)078[1271:SIIAEA]2.0.CO;2.

Hobson, K.A., and Clark, R.G. 1992. Assessing avian diets using stable isotopes I: Turnover of ${ }^{13} \mathrm{C}$ in tissues. Condor, 94(1): 181-188. doi:10.2307/1368807.

Jaksic, F.M., Feinsinger, P., and Jimenez, J.E. 1996. Ecological redundancy and long-term dynamics of vertebrate predators in semiarid Chile. Conserv. Biol. 10(1): 252-262. doi:10.1046/j. 1523-1739.1996.10010252.x.

Kurle, C.M., and Worthy, G.A.J. 2002. Stable carbon and nitrogen isotope ratios in multiple tissues of the northern fur sea Callorhinus ursinus: implications for dietary and migratory reconstructions. Mar. Ecol. Prog. Ser. 236: 289-300. doi:10.3354/meps236289.

MacAvoy, S.E., Macko, S.A., and Arneson, L.S. 2005. Growth versus metabolic tissue replacement in mouse tissues determined by stable carbon and nitrogen isotope analysis. Can. J. Zool. 83(5): 631-641. doi:10.1139/z05-038.

MacAvoy, S.E., Arneson, L.S., and Bassett, E. 2006. Correlation of metabolism with tissue carbon and nitrogen turnover rate in small mammals. Oecologia (Berl.), 150(2): 190-201. doi:10. 1007/s00442-006-0522-0.

McCutchan, J.H., Jr., Lewis, W.M., Jr., Kendall, C., and McGrath, C.C. 2003. Variation in trophic shift for stable isotope ratios of carbon, nitrogen, and sulfur. Oikos, 102(2): 378-390. doi:10. 1034/j.1600-0706.2003.12098.x.

Miller, J.F., Millar, J.S., and Longstaffe, F.J. 2008. Carbon- and nitrogen-isotope tissue-diet discrimination and turnover rates in deer mice, Peromyscus maniculatus. Can. J. Zool. 86(7): 685691. doi:10.1139/Z08-042.

Minagawa, M., and Wada, E. 1984. Stepwise enrichment of ${ }^{15} \mathrm{~N}$ along food chains: further evidence and the relation between $\delta^{15} \mathrm{~N}$ and animal age. Geochim. Cosmochim. Acta, 48(5): 11351140. doi:10.1016/0016-7037(84)90204-7.

Mirón, L.L.M, Herrera M, L.G., Ramírez P, N., and Hobson, K.A. 2006. Effect of diet quality on carbon and nitrogen turnover and isotopic discrimination in blood of a New World nectarivorous bat. J. Exp. Biol. 209(3): 541-548. doi:10.1242/jeb.02016. PMID:16424104.

Peterson, B.J., and Fry, B. 1987. Stable isotopes in ecosystem studies. Annu. Rev. Ecol. Syst. 18(1): 293-320. doi:10.1146/ annurev.es.18.110187.001453.

Phillips, D.L., and Eldridge, P.M. 2006. Estimating the timing of diet shifts using stable isotopes. Oecologia (Berl.), 147(2): 195203. doi:10.1007/s00442-005-0292-0. 
Phillips, D.L., and Koch, P.L. 2002. Incorporating concentration dependence in stable isotope mixing models. Oecologia (Berl.), 130: 114-125. doi:10.1007/s004420100786.

Post, D.M., Layman, C.A., Arrington, D.A., Takimoto, G., Quattrochi, J., and Montaña, C.G. 2007. Getting to the fat of the matter: models, methods and assumptions for dealing with lipids in stable isotope analyses. Oecologia (Berl.), 152(1): 179-189. doi:10.1007/s00442-006-0630-x.

Robbins, C.T., Felicetti, L.A., and Sponheimer, M. 2005. The effect of dietary protein quality on nitrogen isotope discrimination. Oecologia (Berl.), 144(4): 534-540. doi:10.1007/s00442-0050021-8.

Romanek, C.S., Gaines, K.F., Bryan, A.L., Jr., and Brisbin, I.L., Jr. 2000. Foraging ecology of the endangered wood stork recorded in the stable isotopes signature of feathers. Oecologia (Berl.), 125(4): 584-594. doi:10.1007/s004420000471.

SAS Institute Inc. 1985. SAS user's guide: statistics. Version 5 ed. SAS Institute Inc., Cary, N.C.

Sieg, C.H. 1988. Small mammals: pests or vital components of the ecosystem. In Eighth Great Plains Wildlife Damage Control Workshop Proceedings, Rapid City, S.D., 28-29 April 1987. U.S. For. Serv. Gen. Tech. Rep. RM-154. pp. 88-92.

Tieszen, L.L., and Farge, T. 1993. Effect of diet quality and composition on the isotopic composition, $\mathrm{CO}_{2}$, bone collagen, bioapatite, and soft tissues. In Molecular archeology of prehistoric human bone. Edited by J. Lambert and G. Groupe. SpringerVerlag, Berlin, Germany. pp. 123-135.

Tieszen, L.L., Boutton, T.W., Tesdahl, K.G., and Slade, N.A. 1983. Fractionation and turnover of stable carbon isotopes in animal tissues: implications for $\delta^{13} \mathrm{C}$ analysis of diet. Oecologia (Berl.), 57(1-2): 32-37. doi:10.1007/BF00379558.

Tsahar, E., Wold, N., Ishaki, I., Arad, Z., and Martínez Del Rio, C. 2007. Diet influences the rate of ${ }^{15} \mathrm{~N}$ incorporation in the blood cells and plasma of yellow-vented bulbuls (Pycnonotus xanthopygos). J. Exp. Biol. 200: 459-465. doi:10.1242/jeb.013219.

Vanderklift, M.A., and Ponsard, S. 2003. Sources of variation in consumer-diet $\delta^{15} \mathrm{~N}$ enrichment: a meta-analysis. Oecologia (Berl.), 136(2): 169-182. doi:10.1007/s00442-003-1270-z. 